\title{
Stig A. Nohrstedt (ed.): Communicating Risks: Towards the Threat Society? Göteborg: Nordicom. 2010.
}

\author{
Kirsten Mogensen
}

MedieKultur 2013, 54, 206-209

Published by SMID | Society of Media researchers In Denmark | www.smid.dk The online version of this text can be found open access at www.mediekultur.dk

In the decade following the terror attacks on September 11, 2001, a number of media scholars have examined how the media cover risks and threats. Some of them claim that the media not only report about risks, but that they actively contribute to a sense of uncertainty and distrust in the global society. A well-known proponent of this idea is Professor Simon Cottle, Cardiff School of Journalism, Media and Cultural Studies, UK. He has edited a series of books that "examines how the world's media both communicate and constitute global crises on the public stage and thereby help to shape their trajectory around the world."

Another influential scholar working within this framework is Professor Stig A. Nohrstedt from Örebro University, Sweden. In Communicating Risks: Towards the Threat Society?, he has collected analyses of how risks in the first decade of 2000s was mediatized as threats in mass media (p. 10). Most of the analyses in the anthology are written by scholars also associated with Örebro University and most of the cases are Swedish. In other words, the book provides us with empirical data from one region in the world and these empirical data are especially useful for discussion of media power if they are compared with similar studies from other parts of the world.

Two distinct concepts related to this discussion are mediation and mediatization (p.10). The term "mediation" is used to describe the process whereby mass media provide the citizens with information, including information about problems and dangers like climate changes. However, as suggested by Cottle and others, "mediatization" implies that the media themselves construct threats that then require actions from politicians and others 
(p. 41). The concept of mediatization has been used in hundreds of scholarly studies during the first decade of the 2000s. Nohrstedt argues that problems and dangers may be material or social in nature, however, they do not exist as crises without the public attention that mass media create (p.45). As a consequence, mass media have a major impact on how society reacts and their influence is growing (p. 10). One reason for this growing influence is that the general public has lost trust in experts who previously was seen as having a "truth monopoly" (p. 20, 21, 34, 45). In other words, media power should be understood in the context of the development of society.

Life is full of risks. As an example, humans have always faced the risks of natural disasters and hunger. That is nothing new. As human societies have developed, new risks related to technological and scientific progress appeared, such as, risks related to nuclear weapons and genetic manipulation. For most of the $1900 \mathrm{~s}$, mass media would inform about such risks and they would ask experts for opinions on how to solve the problems, and then let the experts interpret the risks. Most people still turn to the media for information about risks in society. However, as Ulrich Beck and others have pointed out, people in general are no longer looking to the scientists for a "solid foundation for opinions and political decisions" (p. 21). The mass media increasingly "juxtapose" different scientists' conclusions and question authorities, resulting in growing skepticism regarding traditional authorities. As traditional authorities have lost their truth-monopoly, mass media have filled the gap and have gained increased influence over the public debate. Depending on the coverage, the media can impact us so that we become either more fearful or more trusting (p. 10).

Nohrstedt considers the threat society a later stage of the risk society described by Beck. In the threat society, we are not only focused on the risk of natural disasters or scientific and technological development, but in addition we also fear people that come from different cultures and practice different religions, for example. A premise of the book is that the mass media create or at least increase this fear of others. As an example taken from the book, the media can use semi-mythical and irrational images to construct threats relating to other cultures or individuals and by doing so initiate conflicts. "[W] hen a risk is politicized, it tends to be formulated as a threat" (p. 26). This implies that there is someone out there who deliberately exposes some of us to a danger. "Mediatization" is seen as "the first media-related precondition for differentiating a threat society from a risk society", writes Nohrstedt ( $p$. 42). Five points characterize the political discourse in the threat society according to him:

- Threats and dangers dominate the political rhetoric.

- Political conflicts are increasingly about different priorities between various threats.

- Political changes are driven by worst-case scenarios.

- The dominating threat perceptions replace each other at an increasingly higher pace in the public discourse.

- Political and social identity increasingly takes the shape of a vulnerable and exposed individual who does not dare to trust his/her fellow-citizens (p. 35). 
From my perspective, it may be relevant to ask if the described mediatization is a symptom of the death struggle for mass media as we knew them in the 1900s and to what extend it is relevant for discussions of media power in the present society. Even if experts have lost their truth monopoly, they are generally more trusted by the public than mass media and nothing indicates that mediatization has increased the trust in mass media in general. Since the empirical data for the articles in this book were collected, social media like Facebook have gained influence and traditional mass media have lost audiences. Nohrstedt may have provided us with a description of the situation just before the history of mass media changed. The book does not consider the impact of social media with its friend discourse.

Nohrstedt's analyses of the threat society (introduction plus chapter 1) contain many interesting observations as indicated in this short résumé. However, chapter 1 also contains several pages of comments regarding American politics (pp. 28-35; 43-47) and even though there may be a connection between for example the "war on terror" and the threat society as discussed by Nohrstedt and others, these pages are mostly of historical interest because they reflect the anti-American sentiment among some media scholars during the war on terror after September 11, 2001. The chapter would be more interesting to read and probably have a greater and more lasting impact if it focused on the analyses and descriptions of the threat society in more general terms and left the rest to historians.

Most of the empirically based chapters in the book refer to Nohrstedt's theory, but they do not really enlighten us regarding the threat society. Instead, they explore themes that are well-known in the research community, such as coverage of "the Others", rhetorical analyses of political statements or media use. Also, the conclusions are seldom surprising. The heroes and the villains are those that were seen as politically correct in the Scandinavian media research community in the early 2000s. It would have been more convincing if the roles were sometimes changed. However, the quality of methodology, theory and empirical data used by the authors of the different chapters vary. Some chapters are truly interesting.

As an example, Johanna Jääsaari and Eva Karin Olsson present an eye-opening analysis of how September 11, 2001, changed the journalistic norms for crisis coverage on two Scandinavian public service broadcast stations, Finnish Yleisradio and Sveriges Television. On the day of the terror attacks, these broadcast stations chose to follow normal editorial routines. They prepared well-researched news stories for scheduled programs, and they did not immediately provide live coverage from New York. Jääsaari and Olsson write that the decisions were out of touch with audience expectations and conceived audience "in a rather paternalistic manner" (p. 86). In retrospect, it seems surprising that the Finnish director would not interrupt the broadcast from the parliamentary budget debate, because he found that it would not be possible to deliver a quality report about the events in New York and Washington before there was more information and he also feared the public would panic. The procedures were changed following September 11, 2001, so that these broadcast stations can broadcast live from crisis events in the future. Jääsaari and Olsson have applied a new institutionalist approach to their study and conclude that this: 
[...] perspective can enhance our understanding of how news organizations change their perceptions regarding journalistic practices in times when their legitimacy is being questioned, how they adjust to practices perceived as more successful that have been employed by other news organizations in the field, and how these practices become the prevalent norm in a Threat Society (p. 90).

Anna Roosvall analyzed foreign news articles from the years 1987, 1995 and 2002, and divided them into categories. One of them is what she calls "picture-within-the-picture". On these press photos, there is a "photograph, a poster, a wall-painting or the like" ( $p$. 125) within the picture, such as Chinese people walking in front of a poster of Mao Tsetung. Roosvall found that many of the people portrayed in the pictures within the pictures were powerful men from Muslim countries who appear to have been "[...] captured in such photos because a direct appearance by them needs to be avoided in Western media [...] these perceptions of Middle Eastern men have to do with perception of danger and threat" (p. 126).

While the main topic of the book is mediatization of threats connected to fear and crisis, these depressing terms are constantly seen in contrast to trust, which is interesting because in the 2010s we have experienced a growing community of scholars interested in trust research. The articles in Communicating Risks: Towards the Threat Society? provide scholars with analytical tools that can inspire studies exploring communication creating fear, but also communication contributing to trust. Looking at it from an epistemological viewpoint, the book may be of interest to scholars interested in mediation and mediatization of trust.

\section{Notes}

1. Cardiff School of Journalism, Media and Cultural Studies: http://www.cardiff.ac.uk/jomec/contactsandpeople/profiles/cottle-simon.html (viewed December 1, 2011).

Kirsten Mogensen

Associate Professor in Journalism

Department of Communication, Business and Information Technologies

Roskilde University, Denmark

kmo@ruc.dk 